\title{
FACTORS INFLUENCING THE BANK PROFITABILITY - EMPIRICAL EVIDENCE FROM ALBANIA
}

\author{
Brunilda DURAJ ${ }^{1}$ \\ Elvana $\mathrm{MOCI}^{2}$
}

\begin{abstract}
:
Commercial banks play a vital role in the economic resource allocation of countries. They contribute to economic growth of the country by making funds available for investors to borrow as well as financial deepening in the country. Corporate performance has been one of the most important issues of managers, investors, and analysts. This concern is connected to the significant role of the profitability of corporate organizations in general, and the banks in particular, on the potential growth of the economy as a whole. A study of the determinants of corporate profitability, therefore, could assist management, investors, and government to forecast and deal with the rising uncertainty of the globalised environment. The issue of the determinants of bank profitability is studied by different authors and academic and the purpose of this paper is to investigate the profitability behavior of bank-specific, industry related and macroeconomic determinants. The primary objective is to investigate the determinants of the profitability and to present all the debates through the literature review on the profitability of these important financial institutions, the banks. An important element of the macro-prudential analysis is the evidence of the internal and external factors and their relationship to the profitability of the banking sector and how this relationship is affected by institutional and structural characteristics. On the other hand internal factors of the banks influencing in the profitability are analyzed.
\end{abstract}

Key words: Bank Profitability, Banking Sector, Liquidity

JEL Classification: $G 21, G 1, G 3$

\section{Introduction}

Commercial banks play a vital role in the economic resource allocation of countries (Ongore, 2013). They contribute to economic growth of the country

\footnotetext{
${ }^{1}$ Phd., University of Tirana/Economic Faculty, Finance Department, Albania; email brunildazani@ feut.edu.al

${ }^{2}$ Phd Candidate, email elvanamoci@gmail.com
} 
by making funds available for investors to borrow as well as financial deepening in the country (Otuori, 2013).The financial system of the South Eastern European (SEE) countries is characterized by the dominant role of the banking sector, with the capital market segment for long-term finance being illiquid and, in some cases, underdeveloped, while non-bank financial intermediaries, such as life insurance companies and private pension funds, are still at an embryonic stage of development (Athanasoglou - 2006).

This paper seeks to examine the effect of bank-specific, and macroeconomic variables on the profitability. It focuses on two main directions: Firstly, the literature review on the bank profitability explains why banking activities and performance have attracted the attention of practitioners, policy makers, and researchers alike, making the investigation of bank profitability relevant issue today than in earlier times, secondly an overview of the banking sector in Albania and statistically it proves if the factors taken in analysis are significant and their relation to profitability.

Although net income gives us an idea of how well a bank is doing, it suffers from one major drawback: It does not adjust for the bank's size, thus making it hard to compare how well one bank is doing relative to another. A basic measure of bank profitability that corrects for the size of the bank is the return on assets $(R O A)$. Although $R O A$ provides useful information about bank profitability, we have already seen that it is not what the bank's owners (equity holders) care about most. They are more concerned about how much the bank is earning on their equity investment, an amount that is measured by the return on equity $(R O E)$, the net income per currency of equity capital (Stanley G. Eakins, Frederic S. Mishkin).

\section{Literature Review}

Determinants of bank profitability can be divided in internal and external factors. Internal factors of bank profitability can be defined as those factors that are influenced by the bank's management policy objectives and decisions. Management effects are the results of differences in bank management policies, decisions, objectives, and actions reflected in differences in bank operating results, including profitability. Zimmerman (1996) has mentioned that management decisions, particularly regarding loan portfolio concentration, were an important factor contributing in bank performance. Researchers frequently attribute good bank performance to quality management. Management 
quality is assessed in terms of senior officers' awareness and control of the bank's policies and performance.

Haslem $(1968,1969)$ computed balance sheet and income statement ratios for all the member banks of the US Federal Reserve System in a two-year study. His results indicated that most of the ratios were significantly related to profitability, particularly capital ratios, interest paid and received, salaries and wages. He also stated that a guide for improved management should first emphasize expense management, fund source management and lastly funds use management. Wall (1985) concludes that a bank's asset and liability management, its funding management and the non-interest cost controls all have a significant effect on the profitability record. A number of studies have concluded that expense control is the primary determinant of bank profitability. Expense management offers a major and consistent opportunity for profitability improvement.

The level of staff expenses appears to have a negative impact on banks ROA in the study of Bourke (1989). However, Molyneux (1993) found a positive relationship between staff expenses and total profits.. External determinants of bank profitability are concerned with those factors which are not influenced by specific bank's decisions and policies, but by events outside the influence of the bank. Several external determinants are included separately in the performance examination to isolate their influence from that of bank structure so the impact of the formers on profitability may be more clearly discerned.

The use of GDP growth as a variable does not feature extensively in the literature. However, Hoggarth et.al. (1998) conclude that the behavior of real GDP fails to explain the greater variability of banking sector profits in the UK than in Germany. But they do not say that GDP variability did not affect profits, only that they could not use it to explain different UK/German banks performance. If this variable is not statistically significant in explaining profitability, then the conclusions of the authors are reinforced. Otherwise, the expected sign should be positive since higher growth implies both lower probabilities of individual and corporate default and an easiest access to credit. The effects of inflation can be substantial and undermines the stability of the financial system and the ability of the regulator to control the solvency of financial intermediaries. Revell (1979) noted that variations in bank profitability can be strongly explained by the level of inflation. 


\section{The current situation internationally}

According to Global Financial Stability Report 2014 , until now, banks have focused primarily on raising capital and derisking their balance sheets to meet risk-based requirements. Their focus, however, has now broadened to include other elements of the Basel III regime, often ahead of the mandated schedule (Figure 1). For example, the LR and the supplementary leverage ratio in the United States (both mandatory beginning January 2018), which penalize size, will make it more costly for banks to hold lower-risk assets. New liquidity requirements, such as the liquidity coverage ratio and the net stable funding ratio will induce banks to hold more liquid (low-risk) assets and to rely more on stable funding sources. In this new paradigm-in which banks are facing a combination of low profitability and new regulatory requirementsbanks need to change the way they operate to ensure that they can build and maintain capital buffers without taking excessive risk and still meet credit demand. During the past few years, banks have under taken a number of measures to address these challenges. They have raised capital. They have also worked in other areas, including running off portfolios, selling noncore businesses, and cutting operating costs. But there may be only limited room left for further gains in these areas and more needs to be done

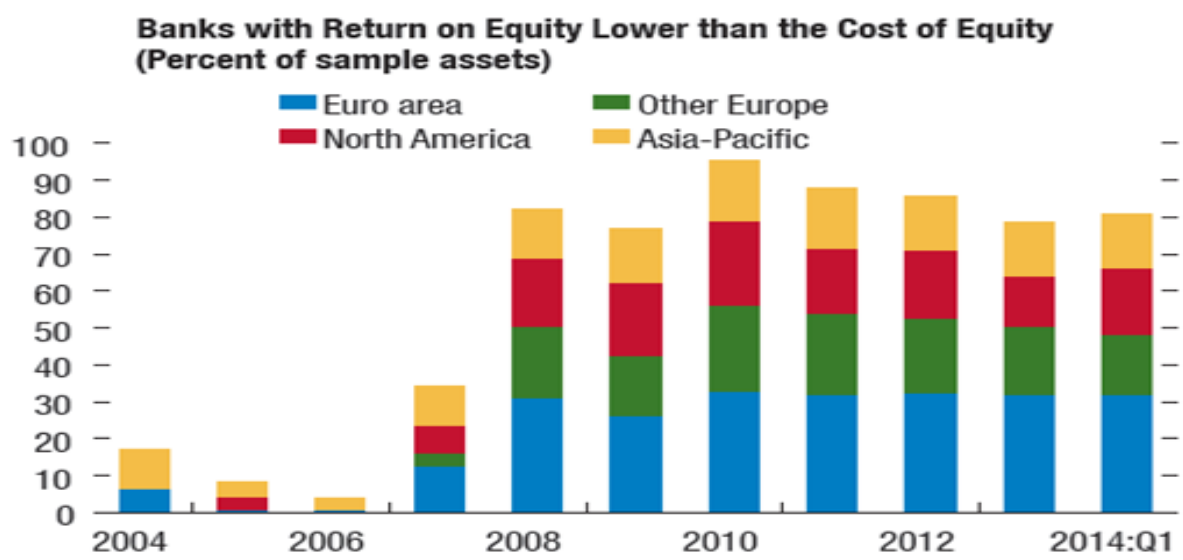

Sources: Bloomberg L.P.; and IMF staff calculations. Note: Based on a sample of about 300 large banks.

Figure 1: Bank Balance Sheets and Profitability

\section{The bank profitability in Albania}

The profitability of the banking sector in Albania results to be high, compared with the Western Balkan countries. The values of the indicators of 
return on assets (ROA) and equity (ROE) remain significantly above the regional average, respectively $0.88 \%$ and $8: 04 \%$. The level of capitalization of our banking sector is satisfactory, and the capital adequacy indicator turns close to the regional average (17.5\%), which is characterized by high values of this indicator. Meanwhile, asset quality remains a major problem as the banking sector and for a part of the Western Balkan countries. However, in our case, the index of non-performing loans resulting on average in the region of $16.2 \%$. In the following part of the paper the empirical result of the banking system indicators of performance and factors influencing in it are presented. Most of the banking literature agrees that a bank's profitability is expected to increase as its portfolio of loans grows in relation to other more secure assets. This greater relative proportion of loans in the portfolio of the bank is usually coupled with a greater liquidity risk arising from the inability of banks to accommodate decreases in liabilities or to fund increases on the assets side of the balance sheet. In Albania the level of total loans has increased during the years (graphic below).According to the literature that should be accompanied with an increase of performance or profitability because higher levels of loans means higher incomes from the loans interest. In our country the result is negative. The figures shows that the increase of the loans' level is not accompanied with the increase of profitability. This might be explained with the increase of the NPL ratio and provision expenses.

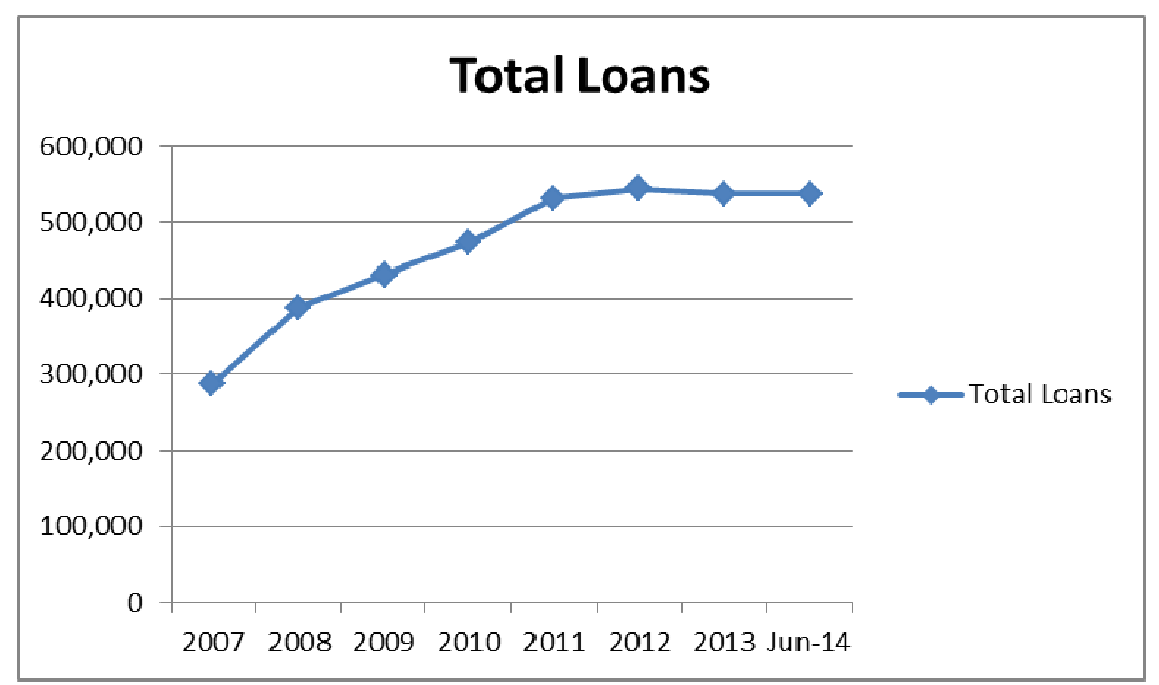

Source BoA, amounts in mil ALL

Graphic 1 
The level of non performing loans has increased dramatically over years. The increase of the NPL is accompanied with increase of provisions from the bank resulting in the decrease of profitability. Even if we take in consideration the literature on the issue on the relationship that exist asset quality and profitabilty there appears to be a consensus that bank profitability is directly related to the quality of the assets on its balance sheet; which means poor credit quality has a negative effect on bank profitability and vice versa. This relationship exists because an increase in the doubtful assets, which do not accrue income, requires a bank to allocate a significant portion of its gross margin to provisions to cover expected credit losses; thus, profitability will be lower.

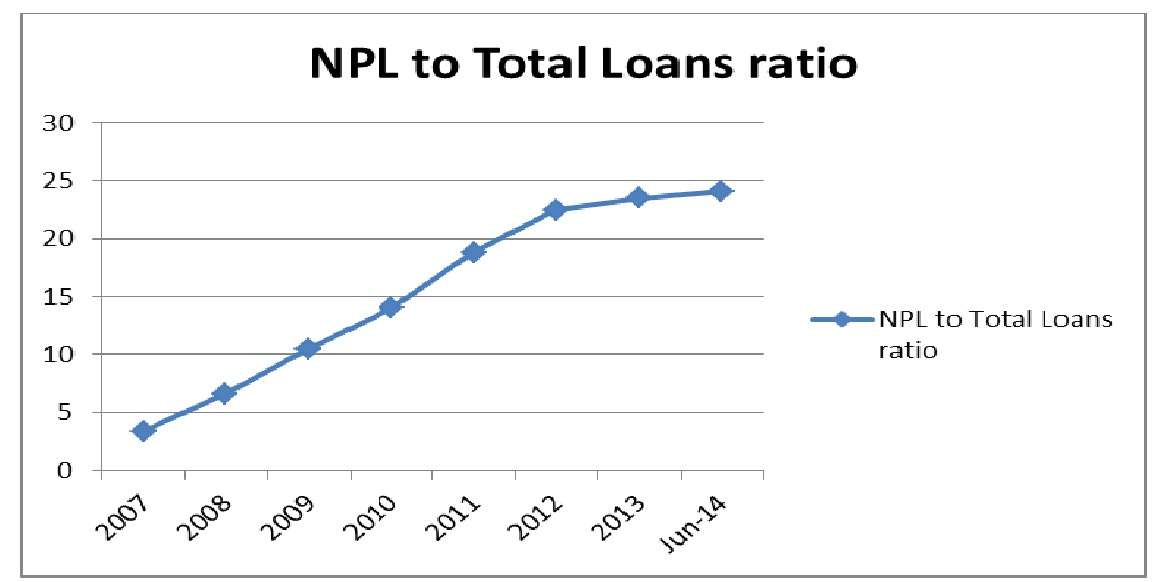

Source BoA

Graphic 2

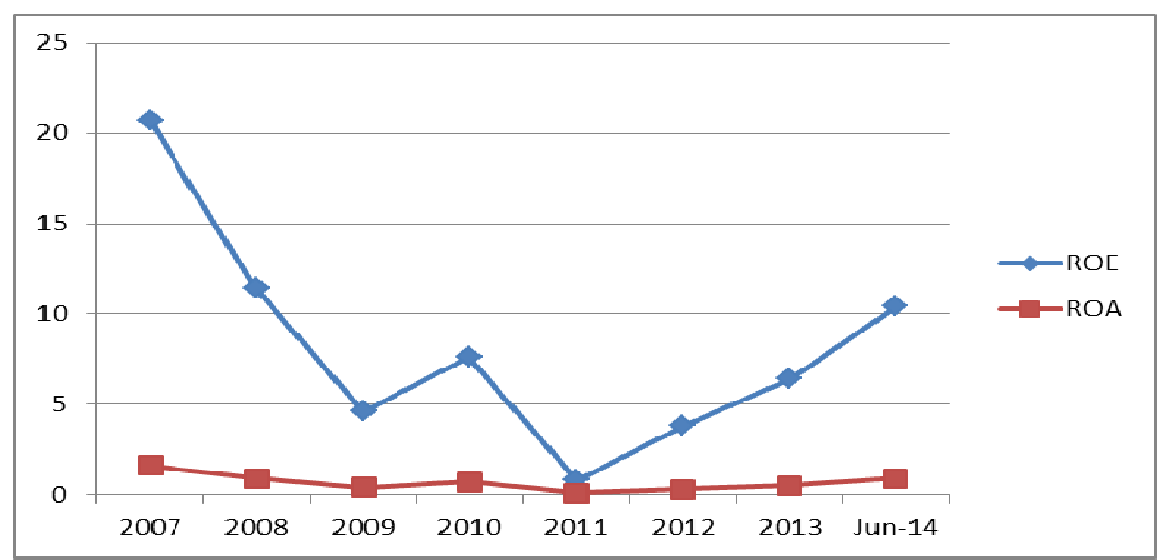

Source BoA

Graphic 3 
According to the literature a higher share of customer deposits in bank liabilities should increase a bank's profitability, considering that deposits constitute a cheap and stable financial resource compared with other financing alternatives (Claeys and Vander Vennet, 2008; García-Herrero et al., 2009) Thus, we examine whether there is a direct relationship between the proportion of customer deposits in a bank's total liabilities and the bank's profitability.

On the other hand, an aggressive competition policy could lead banks to pay higher rates to attract deposits from competitors (the so-called "deposit war"), thus squeezing bank margins. If we analyze the ratio of the deposit to total liabilities of the bank (graphic below) we see that this ratio has been volatile through the years. Both the theories apply in the Albanian banking sector. The "deposit war" has happened among the banks effecting the bank margin. On the other hand this deposit war has happened because as it is explained in the literature the deposits constitute a cheap and stable financial resource. Though we expect that this factor should not explain the change of profitability or said in other words in the future empirical and econometric analysis it is expected that the factor of deposit to total liabilities of the bank to be not significant.

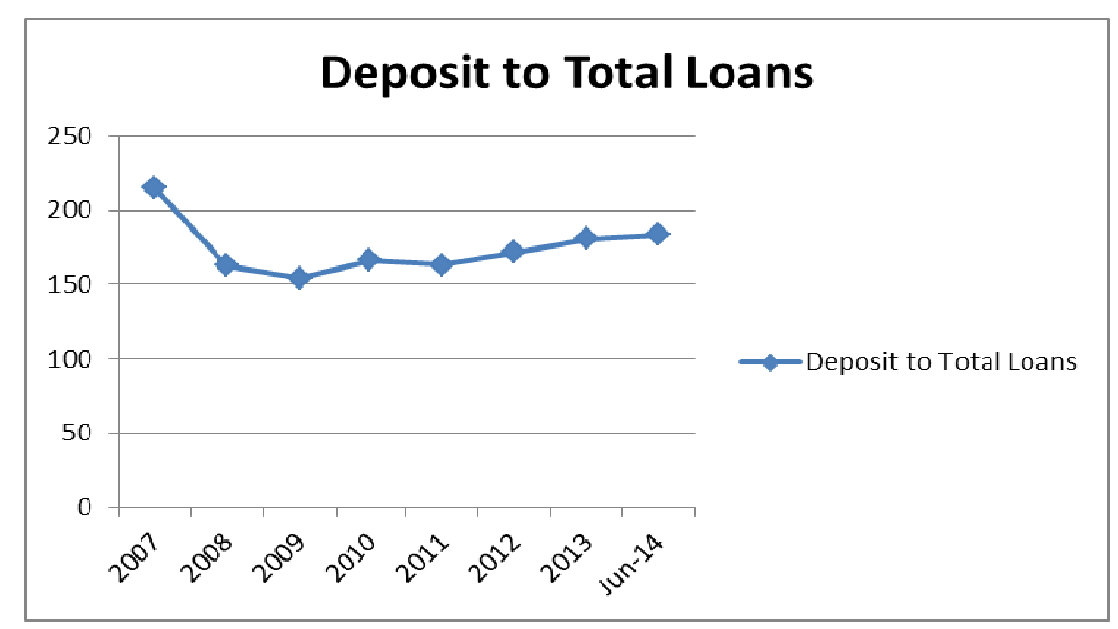

Source BoA

Graphic 4

According to the external factors that influence the banking sector we analyze the GPD and inflation rate. 
During the years the GDP of the country has had an upward slope even though the increase has been in low levels. According to the literature it is expected that the relationship between GDP and profitability to be positive. Poor economic conditions can worsen the quality of the loan portfolio, generating credit losses and increasing the provisions that banks need to hold, thereby reducing bank profitability. In contrast, an improvement in economic conditions, in addition to improving the solvency of borrowers, increases demand for credit by households and firms with positive effects on the profitability of banks.

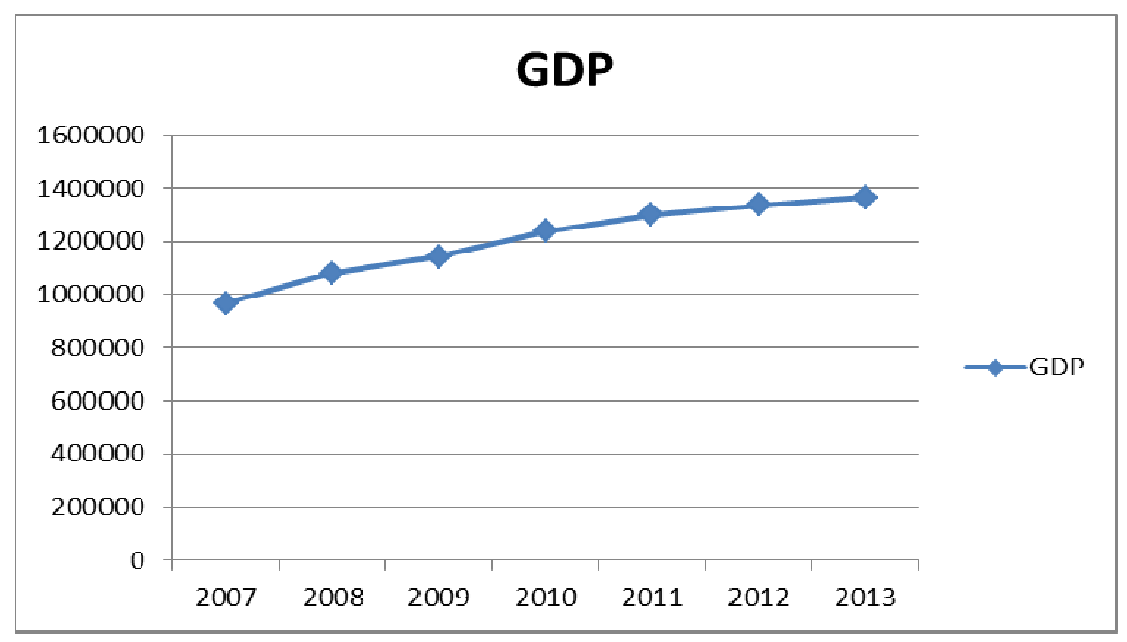

Source BoA

\section{Graphic 5}

According to the literature, Revell (1979) ,introduces the relationship between bank profitability and inflation, stating that the effect of inflation on bank profitability depends on how inflation affects both salaries and the other operating costs of the bank. In this context, Perry (1992) concludes that the extent to which inflation impacts bank profitability depends on whether the extent of inflation is fully anticipated. If the inflation rate is fully anticipated by the bank's management, the bank can adjust interest rates appropriately to increase revenues faster than costs, which should have a positive impact on profitability. Also Demirguc-Kunt and Huizinga (1999) notice that banks in developing countries tend to be less profitable in inflationary environments, particularly when they have a high capital ratio. In these countries, bank costs actually increase faster than bank revenues 
The bank of Albania has tried to maintain the level of inflation between some target points. As it is seen from the graphic through the period 2007-2014 the range level of inflation rate has been 1.63-3.6\%.

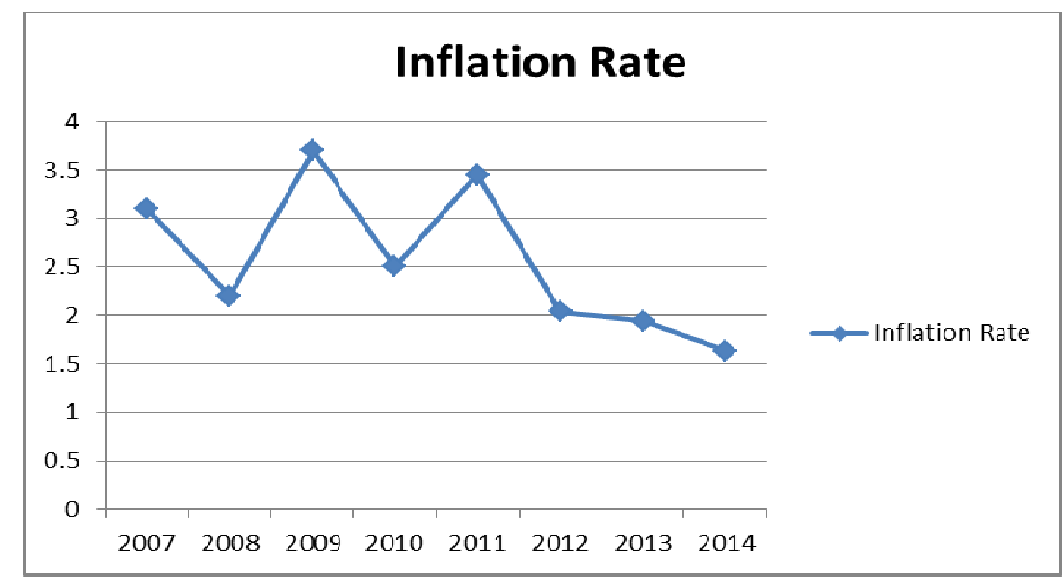

Source BoA

Graphic 6

5. Regression Analysis

Profitability $(\mathrm{ROE})=\beta 0+\beta 1 \mathrm{LQR}+\beta 2 \mathrm{NPL}+\beta 3 \mathrm{LN}+\beta 4 \mathrm{GDP}+$ $\beta 5 \mathrm{INF}+\varepsilon$

Profitability is the dependent variable of this study. Explanation of dependent and independent variables along with their proxies are specified in Table 1

Table 1: Explanation of variables

\begin{tabular}{|l|l|l|}
\hline Varialbles & Symbol & Equation \\
\hline Return on Equity & ROE & Net income / Total Equity \\
\hline Non performing loans rate & NPL & Non-Performing Loans /Total Loans \\
\hline Liquidity risk & LQR & Deposit to Loans ratio \\
\hline Total loans & LN & \\
\hline Gross Domestic Product & GDP & \\
\hline Inflation & INF & \\
\hline
\end{tabular}

We performed multi linear regression analysis with secondary data using a sample of data from 16 banks in the period 1999 - 2014. The confidence level used is $95 \%$ testing the below hypothesis : 
Table 2: Hypothesis List

\begin{tabular}{|l|l|}
\hline Null Hypothesis & Alternative hypothesis \\
\hline $\begin{array}{l}\text { H0- There exist no relationship between NPL } \\
\text { Ratio and profitability. }\end{array}$ & $\begin{array}{l}\text { Ha- There exist relationship between NPL } \\
\text { Ratio and profitability. }\end{array}$ \\
\hline $\begin{array}{l}\text { H0- There exist no relationship between } \\
\text { Deposit to Loans ratio and profitability. }\end{array}$ & $\begin{array}{l}\text { Ha- There exist relationship between Deposit } \\
\text { to Loans ratio and profitability. }\end{array}$ \\
\hline $\begin{array}{l}\text { H0- There exist no relationship between GDP } \\
\text { level and profitability. }\end{array}$ & $\begin{array}{l}\text { Ha- There exist relationship between GDP } \\
\text { level and profitability. }\end{array}$ \\
\hline $\begin{array}{l}\text { H0- There exist no relationship between } \\
\text { Inflation and profitability. }\end{array}$ & $\begin{array}{l}\text { Ha- There exist relationship between } \\
\text { Inflation and profitability. }\end{array}$ \\
\hline $\begin{array}{l}\text { H0- There exist no relationship between Loan } \\
\text { level and profitability. }\end{array}$ & $\begin{array}{l}\text { Ha- There exist relationship between Loan } \\
\text { level and profitability. }\end{array}$ \\
\hline
\end{tabular}

The $\mathrm{R}$ square of $99.7 \%$ shows that the model is significant and that the $99.7 \%$ of the variability of the bank profitability measured through the ROE is explained through the variance of the factor we took in our study as determinant in the bank profitability.

\begin{tabular}{ll} 
Table 3 & \\
\hline Regression Statistics & \\
\hline Multiple R & 0.998487452 \\
R Square & 0.996977192 \\
Adjusted R Square & 0.989420171 \\
Standard Error & 0.006292862 \\
Observations & 24 \\
\hline
\end{tabular}

Source: Authors calculations

From the analysis of the ANOVA we see that significance of the total regression appears to be significant, presented from the $\mathrm{F}$ statistic :

\section{Table 4}

ANOVA

\begin{tabular}{llllll}
\hline & $d f$ & $S S$ & $M S$ & $F$ & Significance $F$ \\
\hline Regression & 5 & 0.083059 & 0.016612 & 64.08086621 & $2.86714 \mathrm{E}-07$ \\
Residual & 10 & 0.002592 & 0.000259 & & \\
Total & 15 & 0.085651 & & & \\
\hline
\end{tabular}

Source : Authors calculations

In order to test which of the factor were significant for the model we did the P -test with $95 \%$ confidence level : 


\section{Table 5}

\begin{tabular}{lllcccc}
\hline & \multicolumn{3}{c}{ Standard } & & & Upper \\
& Coefficients & \multicolumn{1}{c}{ Error } & t Stat & P-value & Lower 95\% & 95\% \\
\hline Intercept & 0.017029169 & 0.09052 & 0.188126 & 0.854540227 & -0.184661475 & 0.21872 \\
NPL Ratio & $-3.09345 \mathrm{E}-05$ & 0.000499 & -0.06195 & 0.951825158 & -0.001143588 & 0.001082 \\
Deposit/Loans & 0.000317256 & $7.4 \mathrm{E}-05$ & 4.287617 & 0.001592171 & 0.000152388 & 0.000482 \\
GDP & $7.30377 \mathrm{E}-07$ & $1.41 \mathrm{E}-07$ & 5.185931 & 0.000409546 & $4.1657 \mathrm{E}-07$ & $1.04 \mathrm{E}-06$ \\
Inflation & -0.014986301 & 0.006237 & -2.40287 & 0.037133122 & -0.028882834 & -0.00109 \\
Loans level & $-1.81373 \mathrm{E}-06$ & $2.45 \mathrm{E}-07$ & -7.39424 & $2.33065 \mathrm{E}-05$ & $-2.36027 \mathrm{E}-06$ & $-1.3 \mathrm{E}-06$ \\
\hline
\end{tabular}

Source : Authors calculations

The results shows that expect the NPL ratio, all the factors were significant, whereas the sign of the relationship between the dependent and the independent variable is explained as below.

- NPL ratio: The result of the multi linear regression model shows that this factor is not significant to explain the bank profitability. The banks in Albania have had a high level of NPL ratio in the recent years, meaning a bad quality of the loan portfolio. This is associated with an increase of the expenses for provisioning and lower ROE. Statististicly this factor is related negatively to the ROE which is relevant. As we explained before the literature shows that this factor is significant to explain the profitability of the banks but in the case of Albania it is not. This is because the loan portfolio quality has been deteriorated in the recent years and even though the increase rate of NPL was smaller compared to previous years, it was because the decrease of the credit in the economy. In the same time, banks to improve the liquidity has had in focus to increase the deposits which we see in the factor we had included in our study, the ratio deposit to loans.

- Deposit/Loans ratio: the result of the regression analysis shows that this factor is significant and related positively. We included this ratio in order to see the impact of the liquidity of the banks in the profitability. The beta coefficient is relatively small but positive meaning that if the banks increase the financing of the loans with deposits it will impact positively the ROE.

- GDP level : The GDP is a factor that is significant and related positively to the profitability. In our analysis, GDP is an external factor, and for its relevancy it is considered as important to be taken in consideration. The increase of the GDP of the country has positive impact in the profitability of the banking sector in Albania associated with the other internal factors that are analyzed. 
- Inflation rate: The inflation appears to be significant and related negatively to the profitability. we mentioned that the results of the other authors were mixed for the impact of the inflation to the profitability. In the Albanian financial sector it appears that with the inflation the operational costs are increased more than the effect of the interest rates resulting in lower profitability for the banks.

- Loans: The total loan level appears to be a significant variable in determining the ROE with negative sign. This is because the impact of the bad quality of loans portfolio which we mentioned is a problematic issue in this market with high level of NPL and high level of provision expenses.

\section{Concluding Remarks}

We believe that testing for the robustness of banks performance over time and space should shed light on policy debates, and on the assessment of banks performance. In addition, we believe that the work has some relevance and importance for the ongoing wave of consolidation banking markets and for the well functioning of it. A linear function of a multiple regression equation, on a pooled cross section time series sample, is utilized in the desperation of the thesis to test the effects of firm and market specific variables on bank profitability. A number of studies have examined bank performance in an effort to isolate the factors that account for interbank differences in profitability. These factors are either internal or external. Individual bank characteristics such as the portfolio composition, and the scale and scope of operations, can affect the costs at which banks produce financial services. We perform time series regressions and yearby-year cross sectional regressions. The estimated results suggests that the profitability of Albanian banks is influenced not only by factors related to their management decisions, internal factors, but also to changes in the external macroeconomic environment. The type of explanation for the level of profitability would determine possible policy implications and ought to be taken seriously. Since very little empirical work has been undertaken investigating the competitive behavior of Albanian banking systems, an empirical investigation like the one conducted above may yield insights that could be of interest to academics, bankers, and policy makers. 


\section{References}

[1] Avkiran, N. K., 2009, Removing the impact of environment with units-invariant efficient frontier analysis: An illustrative case study with intertemporal panel data, Omega 37, 535-544.

[2] Bank Management and Financial Services (7th.2008)- Peter Rose

[3] Barros, C. P., C. Ferreira, and J. Willians, 2007, Analysing the determinants of performance of best and worst European banks: A mixed logit approach, Journal of Banking and Finance 31, 2189-2203.

[4] Berger, A.N., 1995a, The profit-structure relationship in banking: tests of market-power and efficient-structure hypotheses, Journal of Money, Credit, and Banking 27, 404-431.

[5] Bank of Albania Reports

[6] Berger, A.N., 1995b, The relationship between capital and earnings in banking, Journal of Money, Credit, and Banking 27, 432-456.

[7] Berger, A. N., I. Hasan, and M. Zhou, 2010, The effects of focus versus diversification on bank performance: Evidence from Chinese banks, Journal of Banking and Finance 34, 1417-1435.

[8] Berger, A. N., and D. B. Humphrey, 1994, Bank scale economies, mergers, concentration, and efficiency: The U.S. experience. Working paper (The Wharton Financial Institutions Center, USA).

[9] García-Herrero, A., S. Gavilá, and D. Santabárbara, 2009, What explains the low profitability of Chinese banks? Journal of Banking and Finance 33, 2080-2092.

[10] Financial Markets and Institutions, Measuring Bank Performance Stanley G. Eakins, Frederic S. Mishkin

[11] Iannotta, G., G. Nocera, and A. Sironi, 2007, Ownership structure, risk and performance in the European banking industry, Journal of Banking and Finance 31, 2127-2149.

[12] Instat Data- Databaza Statistikore

[13] Ministry Of Finance Reports- Statistika

[14] Stiroh, K.J., and A. Rumble, 2006, The dark side of diversification: The case of US financial holding companies, Journal of Banking and Finance 30, 2131-2161.

[15] IMF website -Global Financial Stability Report 2014, Statistic data

[16] The Determinants Of European Bank Profitability, Staikouras and Wood, 2011 